Section Editor

Mitchell S.V. Elkind, MD, MS

\title{
Teaching NeuroImages: \\ Fetal deep medullary vein thrombosis presenting as progressive intracerebral hemorrhage
}

Ramesh Konanki, DM Dandu Ravi Varma, DM Chinmayee Ratha, MD Lokesh Lingappa, DM Nikit Shah, DNB

Correspondence to

Dr. Ramesh Konanki: rameshkonanki@gmail.com

\section{Figure 1 Antenatal ultrasonography}

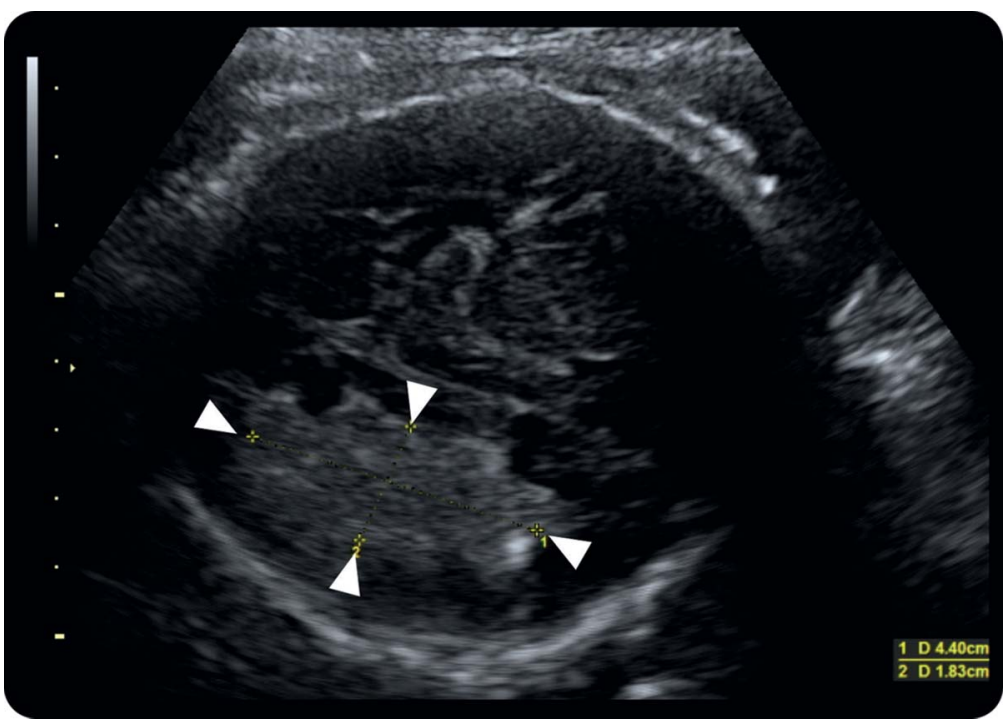

Axial section of the brain from the prenatal sonogram shows a large echogenic lesion in the left cerebral hemispheric white matter (arrowheads).

Figure 2 MRI of brain on day 2 of life
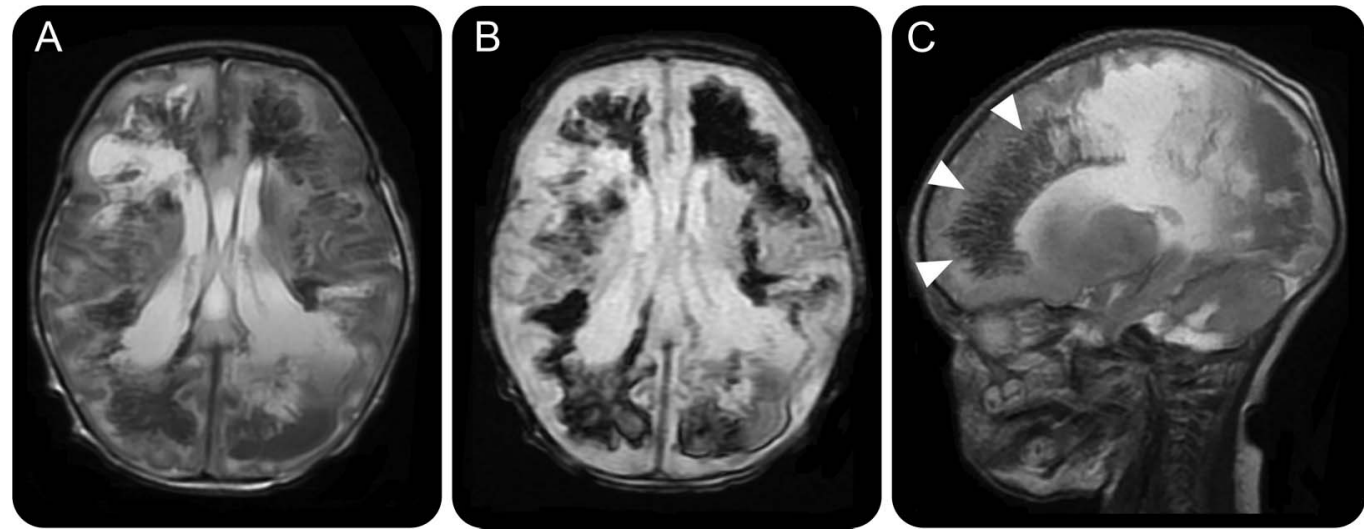

(A) Axial T2 and (B) gradient-recalled echo images of the brain show large parenchymal hemorrhages in the deep white matter of the frontal and parietal lobes. (C) Sagittal T2-weighted image of the brain shows linear hypointense lesions in the frontal periventricular white matter, oriented radially from the ventricular margin. The characteristic fan-shaped orientation of these lesions and involvement of the frontal white matter distinguishes this entity from other more common causes of neonatal intracerebral hemorrhage such as germinal matrix hemorrhage.
Download teaching slides: Neurology.org
From the Departments of Neurology (R.K., N.S., L.L.) and Fetal Medicine (C.R.), Rainbow Hospital for Women and Children; and the Department of Neuroradiology (D.R.V.), Mediciti Hospitals, Hyderabad, India.

Go to Neurology.org for full disclosures. Funding information and disclosures deemed relevant by the authors, if any, are provided at the end of the article. 
A 27-year-old pregnant woman underwent ultrasonography at 36 weeks gestation, which revealed unilateral echogenic lesion (figure 1). Her previous week's scan was normal. Possibilities of intracerebral hemorrhage and neoplasm were considered. The neonate, delivered 7 days later, had seizures on day 1 . The MRI revealed bilateral extensive supratentorial intracerebral hemorrhages (figure 2). The baby died 3 days later due to continuing seizures and raised intracranial pressure. The MRI was characteristic of deep medullary vein (DMV) thrombosis with secondary hemorrhagic infarction. Prothrombotic workup revealed antithrombin III deficiency. The radiating fan-shaped hemorrhages are unique imaging findings of DMV thrombosis, causing substantial morbidity. ${ }^{1,2}$

\section{AUTHOR CONTRIBUTIONS}

R.K., C.R., L.L., and N.S. provided clinical care to the mother and baby and drafted the manuscript. D.R.V. provided radiologic input. All authors read and approved the final version of the manuscript.

\section{STUDY FUNDING}

No targeted funding reported.

\section{DISCLOSURE}

The authors report no disclosures relevant to the manuscript. Go to Neurology.org for full disclosures.

\section{REFERENCES}

1. Arrigoni F, Parazzini C, Righini A, et al. Deep medullary vein involvement in neonates with brain damage: an MR imaging study. AJNR Am J Neuroradiol 2011;32:20302036. doi: 10.3174/ajnr.A2687.

2. Doneda C, Righini A, Parazzini C, Arrigoni F, Rustico M, Triulzi F. Prenatal MR imaging detection of deep medullary vein involvement in fetal brain damage. AJNR Am J Neuroradiol 2011;32:E146-E149. doi: 10.3174/ajnr.A2249. 


\title{
Neurology
}

\author{
Teaching NeuroImages: Fetal deep medullary vein thrombosis presenting as \\ progressive intracerebral hemorrhage \\ Ramesh Konanki, Dandu Ravi Varma, Chinmayee Ratha, et al. \\ Neurology 2015;85; e5-e6 \\ DOI 10.1212/WNL.0000000000001719
}

\section{This information is current as of July 6, 2015}

\section{Updated Information \& Services \\ Supplementary Material}

\section{References}

Citations

Subspecialty Collections

\section{Permissions \& Licensing}

Reprints including high resolution figures, can be found at: http://n.neurology.org/content/85/1/e5.full

Supplementary material can be found at: http://n.neurology.org/content/suppl/2015/07/03/WNL.0000000000001 719.DC1

This article cites 2 articles, 2 of which you can access for free at: http://n.neurology.org/content/85/1/e5.full\#ref-list-1

This article has been cited by 2 HighWire-hosted articles: http://n.neurology.org/content/85/1/e5.full\#\#otherarticles

This article, along with others on similar topics, appears in the following collection(s):

\section{All Cerebrovascular disease/Stroke}

http://n.neurology.org/cgi/collection/all_cerebrovascular_disease_strok e

Cerebral venous thrombosis

http://n.neurology.org/cgi/collection/cerebral_venous_thrombosis

Intracerebral hemorrhage

http://n.neurology.org/cgi/collection/intracerebral_hemorrhage

Information about reproducing this article in parts (figures,tables) or in its entirety can be found online at:

http://www.neurology.org/about/about_the_journal\#permissions

Information about ordering reprints can be found online:

http://n.neurology.org/subscribers/advertise

Neurology ${ }^{\circledR}$ is the official journal of the American Academy of Neurology. Published continuously since 1951 , it is now a weekly with 48 issues per year. Copyright @ 2015 American Academy of Neurology. All rights reserved. Print ISSN: 0028-3878. Online ISSN: 1526-632X.

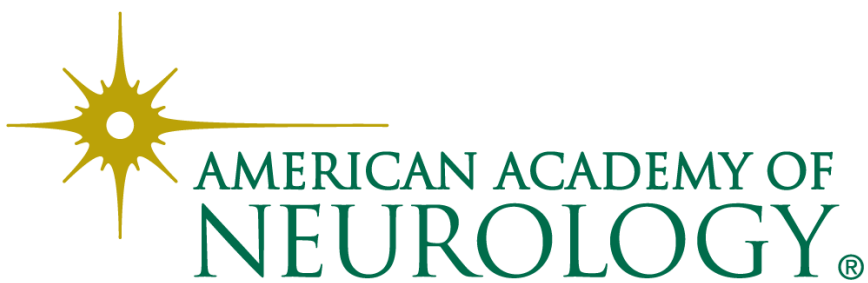

